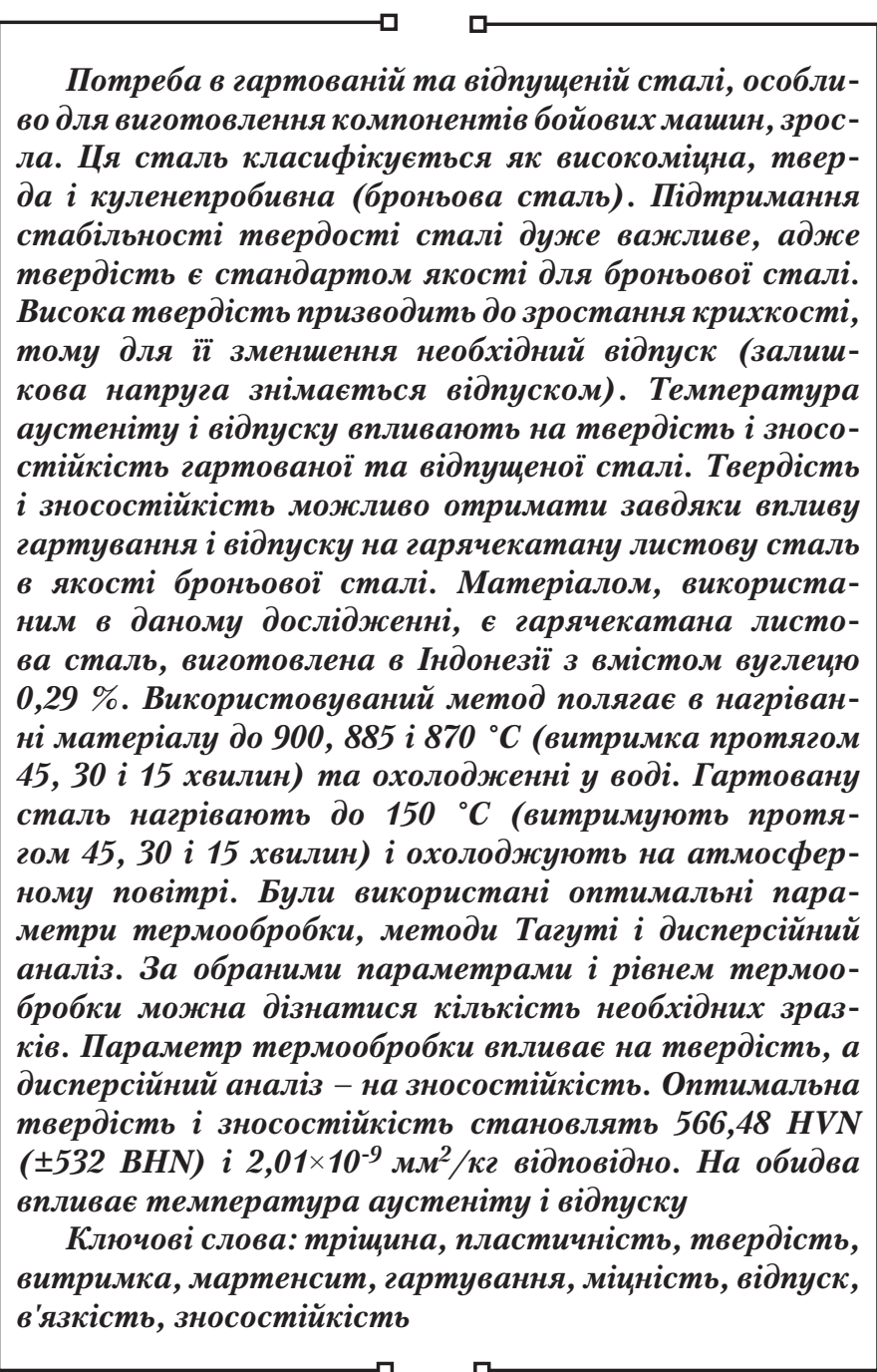

UDC 669.13.018

DOI: $10.15587 / 1729-4061.2019 .156799$

\section{EFFECT OF QUENCH AND TEMPER ON HARDNESS AND WEAR OF HRP STEEL (ARMOR STEEL CANDIDATE)}

Yurianto

Master of Technical Sciences, Associate Professor* E-mail: yurianto@undip.ac.id

Pratikto

Doctor of Technical Sciences, Professor* E-mail: prayone_adi@ub.ac.id

Rudy Soenoko Doctor of Technical Sciences, Professor*

E-mail: rudysoen@ub.ac.id

Wahyono Suprapto

Doctor of Technical Sciences, Professor*

E-mail: wahyos@ub.ac.id

*Department of Mechanical Engineering

Brawijaya University

Jl. Mayjen Haryono, 167, Malang, Indonesia, 65145

\section{Introduction}

High-strength and hardness steel is often used to make bullet-resistant components of military need. The limits for bullet-resistant steel (armor steel) are unclear, and hardness is important [1,2]. Quenched and tempered (Q\&T) steels are used in military applications due to high hardness, high strength to weight ratio, and excellent toughness [3]. Armor steel that has the highest ballistic resistance is AISI 4340 with a hardness of $50 \mathrm{HRC}=485 \mathrm{BHN}$ [4]. Keeping hardness stability is essential because this is a quality standard for armor steels. High hardness causes brittleness increase, and tempers are needed to increase ductility (residual stress is relieved by temper). The austenite and temper temperature will affect the Q\&T Steel hardness and wear resistance. Then the use of the optimum austenite and temper temperature is very important to obtain the hardness and wear of quenched and tempered steel.

So far, no researcher has examined the optimization of quench and tempering heat treatment parameters against hardness and wear. This research is an attempt to obtain hardness and wear that are influenced by austenite temperature, austenite holding time, and temper holding time. So this is the novelty of this research.

\section{Literature review and problem statement}

Coarse austenites are obtained at the higher austenite temperature because of grain growth, and quenching produces coarse martensite. The austenite temperature is closest to $\mathrm{Ar}_{3}$, the fine martensite is produced and expressed by [5],

$$
\begin{aligned}
& \mathrm{Ar}_{3}=(\mathrm{C}) \approx 910-(310 \mathrm{C})-(80 \mathrm{Mn})- \\
& -(80 \mathrm{Mo})-(55 \mathrm{Ni})-(20 \mathrm{Cu})-(15 \mathrm{Cr}) .
\end{aligned}
$$

Austenite transforms to martensite at the end of the quench. Martensite starts to form at temperature $\mathrm{M}_{\mathrm{s}}$ and finishes at temperature $\mathrm{M}_{\mathrm{F}}$, and both temperatures are expressed by [6],

$$
\begin{aligned}
& M_{s}(\mathrm{C}) \approx 561-(474 \mathrm{C})-(33 \mathrm{Mn})- \\
& -(17 \mathrm{Ni})-(17 \mathrm{Cr})-(21 \mathrm{Mo}) . \\
& M_{F}(\mathrm{C})=175{ }^{\circ} \mathrm{C}-165^{\circ} \mathrm{C} \text { below } \mathrm{M}_{\mathrm{s}} .
\end{aligned}
$$

Ductility of quenched steel can be increased using temper, and quenched and tempered steels are produced. Tempering temperature, which reduces the residual stress due to previous quenching, is $150{ }^{\circ} \mathrm{C}$ [7]. Wear is related to hardness, fracture resistance, and thermal stability for 
high-temperature wear [8]. Increased carbon concentration systematically lowers $\mathrm{M}_{\mathrm{s}}$ temperature and increases alloy hardness [9]. By transforming lath sub-structure bainite into cells at high tempering temperature, the fine grains are produced [10]. The hardness decreases with increasing temper temperature, which produces a corresponding increase in penetration depth [11]. With the addition of carbon elements, the tensile strength increases with a slight increase in martensite transformation temperature. Broader distribution of martensite in good auto-tempered steel can help ductility increase by increasing work-hardenability during tension [12]. While at higher austenitization temperatures and longer austenitization times, the larger grains are produced [13]. Martensite abrasion is not guaranteed compared to lower hardness, which has better ductility. The brittle martensite properties have lower wear resistance [14]. Heat treated steel improves its service conditions, especially in creep resistance [15] and is suiTable for continuous heat exposure. The contribution of strength is because the dislocation density is higher than the strengthening precipitation of tempered martensite. Samples that were rapidly tempered contributed to higher precipitation strength than tampered slowly [16].

The martensite carbon content depends on the volume of ferrite and martensite fractions developed as a transformation result of the ferrite and martensite phases after successful immersion and quenching [17]. Because the dislocation density and martensite carbon content decrease due to temper, the martensite strength decreases. The remaining residual strain is indicated by mean kernel misorientation, which is allowed by reorganization or destruction of dislocation geometrically [18].

The micro-spherical structure shows resistance to wear. Therefore, spheroidized heat treatment processes can be used to reduce wear in ultra-high carbon steel [19]. High-carbon martensite steel has poor ductility [20]. Smoother surfaces produce a lower coefficient of friction [21]. The fine grain structure produces a smooth surface and ductility increases, and wear resistance increases. The specific wear is calculated by the following for formula [22],

$$
S W=\frac{B \times B_{o}^{2}}{8 r \times P_{o} \times L_{o}},
$$

where $B$ - width of the rotating disk; $B_{0}$ - length of wear; $r$ - radius of the disk; $P_{o}$ - load given; $L_{o}$ - abrasion distance.

The resistance of materials to indentation is hardness, and Vickers and Brinell hardness number - BHN is used in this research.

The Taguchi methods are used to improve product quality and processes. At the same time, this method can reduce the costs and the resources as low as possible, and they are strong to the disturbance factor. Processing of data is made using equations (5) to (20) [23, 24]. The first step is to create a design that includes a combination of parameters and levels and the determination of orthogonal matrices. For more accurate data of each parameter, two replications are made. The orthogonal matrix (OM) is determined by the following formula,

$$
O M=L_{a} b^{c},
$$

where $L$ - symbol of the orthogonal matrix; $a$ - number of experiments; $b$ and $c$ - level and control factor, respectively.
The second step is to interpret the tested data by calculating the response ratio with the following equation.

For hardness, Larger the better (LTB),

$$
\frac{S}{n} \text { ratio }=-10 \log _{10}\left[\frac{1}{n} \sum_{i=1}^{n} \frac{1}{y_{i}^{2}}\right] \text {. }
$$

For specific resistance, Smaller the better (STB) is expressed,

$$
\frac{S}{n} \text { ratio }=-10 \log _{10}\left[\frac{1}{n} \sum_{i=1}^{n} y^{2}\right],
$$

where $\frac{S}{n}$ ratio - signal to noise ratio; $y$ - response value.

The $\frac{S}{n}$ ratio shows how strong the test parameters are in interference. The higher the $\frac{S}{n}$ ratio the strongest their parameters and the results can be used to strengthen for average response data.

ANOVA calculations include calculation of the sum of the total error and parameters level $n$ and use the following equations (8) to (11) [23, 24],

$$
\begin{aligned}
& S_{t}=\sum R^{2} ; \\
& S_{m}=n \times \bar{R}^{2} ; \\
& S_{p}=\frac{\left[L_{1}\right]^{2}}{n_{A_{1}}}+\frac{\left[L_{2}\right]^{2}}{n_{A_{2}}}+\frac{\left[L_{3}\right]^{2}}{n_{A_{3}}}-\frac{[T]}{N} ; \\
& S_{e}=S_{t}-S_{m}-S_{p},
\end{aligned}
$$

where $S_{t}$ - sum of the total square; $S_{m}$ - sum of the square mean; $S_{p}$ - sum of the square parameter; $L$ - level, $T$ - sum of average data; $S_{e}$ - sum of the total error.

Contribution values $(p A \%)$ for each parameter to response are calculated using equations (12) to (15) [23, 24],

$$
\begin{aligned}
& M S=\frac{S A}{S_{e}} \\
& F_{\text {ratio }}=\frac{M S}{S_{e}} ; \\
& S A^{\prime}=S_{A}-v A \times V e ; \\
& p A(\%)=\frac{S A^{\prime}}{S_{t}} \times 100 \%,
\end{aligned}
$$

where $M S$ - average square response; $v A$ - degree of freedom; Ve - varian $\left(\sigma^{2}\right) ; S A^{\prime}$ - actual number of the squares of the factor.

To conclude the parameter effect on the response and essential parameters in calculating the optimal response predictive, ANOVAs are used. If $F_{\text {ratio }}>F_{\text {total }}$, the parameter does not have a significant effect on the response and vice versa.

The optimal predictive value and confidence interval $(C I)$ of the research are calculated by equations,

$$
n_{\text {eff }}=\frac{\text { sum of total experiment }}{1+\text { sum of prediction degree of freedom }} ;
$$




$$
C I=\sqrt{\frac{F_{\alpha, v_{1}, v_{2}} \times V e}{n_{e f f}}},
$$

where $\alpha$ - level of confidence; $v_{1}$ - quantifier of trust for the degree of freedom. $v_{2}-$ denominator of pool error for the degree of freedom.

\section{The aim and objectives of the study}

The study aims to obtain hardness and wear due to the influence of quench and temper on hot rolled plate steel as the armor steel candidate.

The following objectives achieve the aim accomplished:

- select heat treatment parameters and level, hardness and wear, and arranged in an orthogonal matrix and its levels;

- determine hardness and wear based on heat treatment parameter optimization;

- interpretation of austenite, holding time, and temper has an influence on hardness and wear.

\section{Material and method of the research}

\section{1. Material}

The material used during the research was hot rolled steel (raw material of quenched and tempered steels.) made by PT. Krakatau Steel (Persero), Cilegon, Banten Province, Indonesia. This material was produced in 2008. Generally, this steel is used to make components that need high hardness and strength.

\section{2. Method of the research}

The heat treatment parameters used are the austenite temperature (A), austenite holding time (B), and tempering temperature (C). While the response used are hardness and wear (both hardness and wear were carried out in two replications) before and after heat treatment condition. All of them are arranged in an orthogonal matrix.

Equations (4)-(16) were used to determine the hardness, wear, and heat treatment parameters (including levels), then processed using Minitab 18 software.

The cooling media used in quenching heat treatment is water because easily controlled, comforTable to obtain and the cheapest than the other, and influence on wear and impact.

The nine specimens each were heated as follows: $870{ }^{\circ} \mathrm{C}$ (holding time 15 minutes); $870{ }^{\circ} \mathrm{C}$ (holding time $30 \mathrm{~min}$ utes); $870{ }^{\circ} \mathrm{C}$ (holding time 45 minutes); $885^{\circ} \mathrm{C}$ (holding time 15 minutes); $885^{\circ} \mathrm{C}$ (holding time 30 minutes); $885^{\circ} \mathrm{C}$ (holding time 45 minutes); $900{ }^{\circ} \mathrm{C}$ (holding time 15 minutes); $900{ }^{\circ} \mathrm{C}$ (holding time 30 minutes); $900{ }^{\circ} \mathrm{C}$ (holding time 45 minutes). Then each specimen was quenched in a water medium. After quenching, heating was carried out at $150{ }^{\circ} \mathrm{C}$ and held for 30 minutes for each specimen. Heating was carried out using a NABERTHERM heating furnace with a maximum temperature of $1100{ }^{\circ} \mathrm{C}$.

Each specimen was tested using microhardness Vickers ZWICK Type Zhu and Ogoshi wear testing machines made by Tokyo Testing machines.

\section{Results of the research}

Observation of the chemical elements contained in HRP Steel is shown in Table 1. Temperatures $A r_{3}, M_{s}$ and
$M_{F}$ are determined by the formula (1) to (3) and shown in Table 2.

Table 1

Chemical elements of HRP Steel

\begin{tabular}{|c|c|c|c|c|c|c|c|}
\hline $\begin{array}{c}\text { Ele- } \\
\text { ment }\end{array}$ & $\mathrm{C}$ & $\mathrm{Cr}$ & $\mathrm{Cu}$ & $\mathrm{Mn}$ & $\mathrm{Mo}$ & $\mathrm{Ni}$ & $\mathrm{Fe}$ \\
\hline $\begin{array}{c}\% \\
\text { weight }\end{array}$ & 0.29342 & 0.55029 & 0.08337 & 1.41218 & 0.19303 & 0.27877 & 97.18894 \\
\hline
\end{tabular}

Table 2

Temperature, hardness and wear of HRP Steels

\begin{tabular}{|c|c|c|c|c|}
\hline $\mathrm{Ar}_{3}$ & $M_{s}$ & $M_{F}$ & Hardness & $S W$ \\
\hline $765{ }^{\circ} \mathrm{C}$ & $357{ }^{\circ} \mathrm{C}$ & $\begin{array}{c}182{ }^{\circ} \mathrm{C} \text { to } \\
192{ }^{\circ} \mathrm{C}\end{array}$ & $\begin{array}{c}288 \mathrm{HVN} \\
(273 \mathrm{BHN})\end{array}$ & $7.34 \times 10^{-9} \frac{\mathrm{mm}^{2}}{\mathrm{~kg}}$ \\
\hline
\end{tabular}

Based on equation (5), heat treatment parameters and responses in the orthogonal matrix $\mathrm{L}_{9}\left(3^{4}\right)$ for hardness, average hardness, and hardness to levels are shown in Tables 3, 4, respectively. Minitab processes Tables 3, 4 and Fig. 1 was obtained. $\frac{S}{n}$ of hardness ratio and $\frac{S}{n}$ of average hardness and $\frac{S}{n}$ ratio of hardness to level parameters are shown in Tables 5, 6, respectively, and using Minitab Fig. 2 was obtained.

The results of ANOVA calculation for hardness are shown in Tables 7,8 .

Wear, average wear and wear to levels are shown in Tables 9, 10 respectively. Average specific wear to level parameters are shown in Fig. 3. The results of $\frac{S}{n}$ for specific wear and average $\frac{S}{n}$ ratio for specific wear are shown in Table 11 and Table 12 , respectively. Average $\frac{S}{n}$ ratio of specific wear to level parameters is shown in Fig. 4. The results of the calculation by ANOVA for specific wear are shown in Tables 13, 14.

Table 3

Hardness

\begin{tabular}{|c|c|c|c|c|c|c|}
\hline Specimen & $A$ & $B$ & $C$ & $H_{A}$ & $H_{B}$ & $H_{C}$ \\
\hline 1 & 870 & 15 & 125 & 571 & 552 & 561 \\
\hline 2 & 870 & 30 & 150 & 533 & 533 & 542 \\
\hline 3 & 870 & 45 & 175 & 551 & 533 & 524 \\
\hline 4 & 885 & 15 & 150 & 524 & 533 & 533 \\
\hline 5 & 885 & 30 & 175 & 515 & 505 & 490 \\
\hline 6 & 885 & 45 & 125 & 542 & 542 & 551 \\
\hline 7 & 900 & 15 & 175 & 515 & 515 & 515 \\
\hline 8 & 900 & 30 & 125 & 571 & 581 & 571 \\
\hline 9 & 900 & 45 & 150 & 542 & 551 & 542 \\
\hline
\end{tabular}

Table 4

Average hardness

\begin{tabular}{|c|c|c|c|}
\hline Level & $A$ & $B$ & $C$ \\
\hline 1 & 544.44 & 535.44 & 560.11 \\
\hline 2 & 526.00 & 537.89 & 537.00 \\
\hline 3 & 544.78 & 541.89 & 518.11 \\
\hline Difference & 18.78 & 6.44 & 42.00 \\
\hline Rank & 2 & 3 & 1 \\
\hline
\end{tabular}




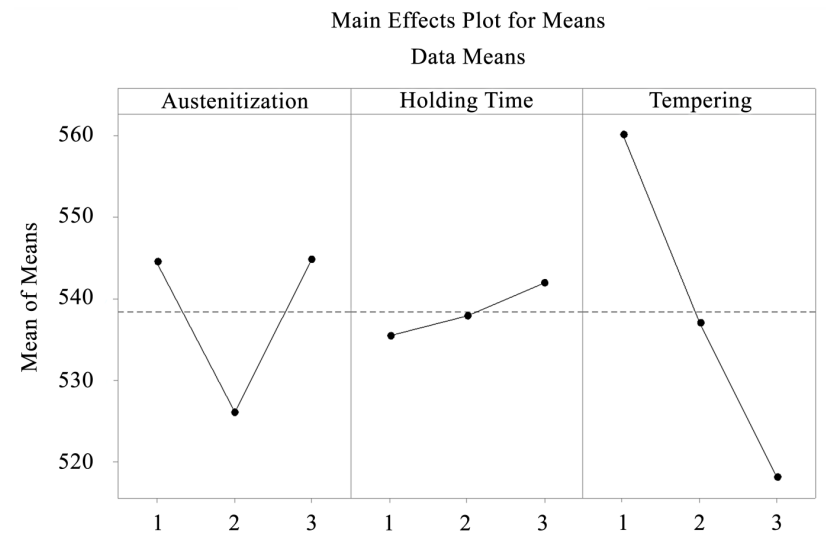

Fig. 1. Graph of average hardness to level parameters

\begin{tabular}{|c|c|c|c|c|}
\multicolumn{5}{c}{$\frac{S}{n}$ hardness ratio } \\
\hline Specimen & $A$ & $B$ & $C$ & ratio $\frac{S}{n}$ \\
\hline 1 & 870 & 15 & 125 & 54.9819 \\
\hline 2 & 870 & 30 & 150 & 54.5825 \\
\hline 3 & 870 & 45 & 175 & 54.5776 \\
\hline 4 & 885 & 15 & 150 & 54.4847 \\
\hline 5 & 885 & 30 & 175 & 54.0316 \\
\hline 6 & 885 & 45 & 125 & 54.7217 \\
\hline 7 & 900 & 15 & 175 & 54.2361 \\
\hline 8 & 900 & 30 & 125 & 55.1824 \\
\hline 9 & 900 & 45 & 150 & 54.7271 \\
\hline
\end{tabular}

Average $\frac{S}{n}$ ratio of hardness

Table 6

\begin{tabular}{|c|c|c|c|}
\hline Level & $A$ & $B$ & $B$ \\
\hline 1 & 54.7140 & 54.56758 & 54.96202 \\
\hline 2 & 54.4127 & 54.59885 & 54.5981 \\
\hline 3 & 54.7152 & 54.67551 & 54.28181 \\
\hline Difference & 0.3025 & 0.1079 & 0.6802 \\
\hline Rank & 2 & 3 & 1 \\
\hline
\end{tabular}

Main Effects Plot for SN ratios Data Means

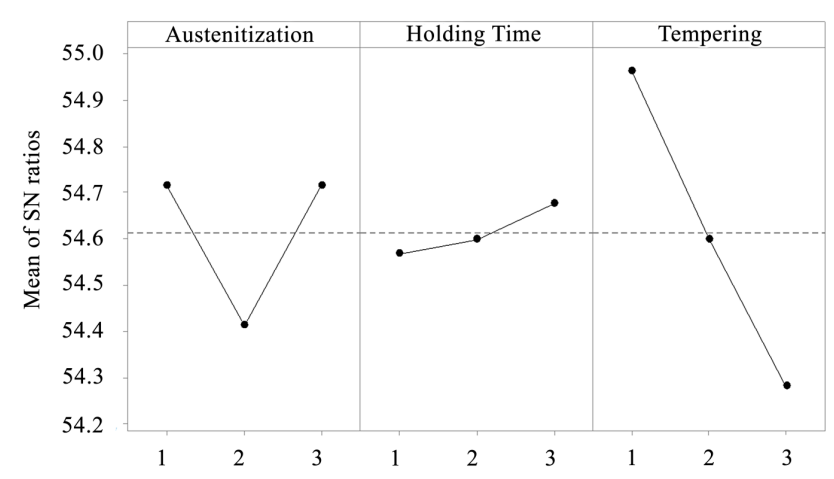

Fig. 2. Graph of average $\frac{S}{n}$ ratio of hardness to level parameters
Table 7

ANOVA of Hardness

\begin{tabular}{|c|c|c|c|c|c|c|}
\hline Source & $S_{\text {source }}$ & $v A$ & $M_{\text {source }}$ & $F_{\text {ratio }}$ & $F_{\text {total }}$ & $p A \%$ \\
\hline Austenitize (A) & 2078.74 & 2.00 & 1039.37 & 9.41 & 3.49 & 16.71 \\
\hline Holding (B) & 190.52 & 2.00 & 95.26 & 0.86 & 3.9 & 1.53 \\
\hline Tempering (C) & 7964.74 & 2.00 & 3982.37 & 36.06 & 3.49 & 64.01 \\
\hline Pool Error & 2208.52 & 20.00 & 110.43 & - & - & 17.75 \\
\hline Total-1 & 12442.52 & - & - & - & - & 100.00 \\
\hline
\end{tabular}

Table 8

Updated ANOVA of Hardness

\begin{tabular}{|c|c|c|c|c|c|c|}
\hline Source & $S_{\text {source }}$ & $v A$ & $M_{\text {source }}$ & $F_{\text {ratio }}$ & $F_{\text {total }}$ & $p A \%$ \\
\hline Austenitize (A) & 2078.74 & 2.00 & 1039.37 & 9.41 & 3.49 & 16.71 \\
\hline Tempering (C) & 7964.74 & 2.00 & 3982.37 & 36.06 & 3.49 & 64.01 \\
\hline Pool. Error & 2399.04 & 22.00 & 205.69 & - & - & 19.28 \\
\hline Total-1 & & & & & & 100 \\
\hline
\end{tabular}

Table 9

Specific wear Test Results

\begin{tabular}{|c|c|c|c|}
\hline \multirow{2}{*}{ Specimen } & \multicolumn{2}{|c|}{ Replication } & $\begin{array}{c}\text { Average Specific Wear } \\
\mathrm{mm}^{2}\end{array}$ \\
\cline { 2 - 3 } & $S W_{1}$ & $S W_{2}$ & $\mathrm{~kg}$ \\
\hline 1 & $2.11 \times 10^{-9}$ & $2.46 \times 10^{-9}$ & $2.28 \times 10^{-9}$ \\
\hline 2 & $1.95 \times 10^{-9}$ & $2.11 \times 10^{-9}$ & $2.03 \times 10^{-9}$ \\
\hline 3 & $2.28 \times 10^{-9}$ & $1.95 \times 10^{-9}$ & $2.11 \times 10^{-9}$ \\
\hline 4 & $2.85 \times 10^{-9}$ & $2.85 \times 10^{-9}$ & $2.85 \times 10^{-9}$ \\
\hline 5 & $2.46 \times 10^{-9}$ & $2.65 \times 10^{-9}$ & $2.55 \times 10^{-9}$ \\
\hline 6 & $1.95 \times 10^{-9}$ & $2.46 \times 10^{-9}$ & $2.20 \times 10^{-9}$ \\
\hline 7 & $2.65 \times 10^{-9}$ & $3.05 \times 10^{-9}$ & $3.85 \times 10^{-9}$ \\
\hline 8 & $3.05 \times 10^{-9}$ & $2.65 \times 10^{-9}$ & $2.85 \times 10^{-9}$ \\
\hline 9 & $4.80 \times 10^{-9}$ & $2.38 \times 10^{-9}$ & $3.54 \times 10^{-9}$ \\
\hline
\end{tabular}

Table 10

Average Specific Wear to Level Parameters

\begin{tabular}{|c|c|c|c|}
\hline Level & $\begin{array}{c}\text { Austenitiza- } \\
\text { tion (A) }\end{array}$ & Holding time & Tempering \\
\hline 1 & $2.14 \times 10^{-9}$ & $2.66 \times 10^{-9}$ & $2.45 \times 10^{-9}$ \\
\hline 2 & $2.53 \times 10^{-9}$ & $2.48 \times 10^{-9}$ & $2.80 \times 10^{-9}$ \\
\hline 3 & $3.08 \times 10^{-9}$ & $2.62 \times 10^{-9}$ & $2.51 \times 10^{-9}$ \\
\hline Difference & $0.94 \times 10^{-9}$ & $0.18 \times 10^{-9}$ & $0.35 \times 10^{-9}$ \\
\hline Rank & 1 & 3 & 2 \\
\hline
\end{tabular}

Main Effects Plot for Means Data Means

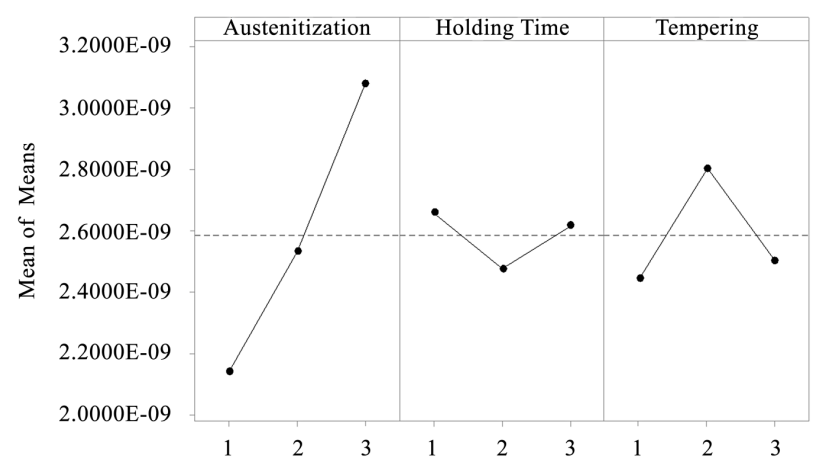

Fig. 3. Graph of average Specific Wear to Level Parameters 
Table 11

Results of calculation of $\frac{S}{n}$ specific wear

\begin{tabular}{|c|c|c|c|}
\hline \multirow{2}{*}{ Specimen } & \multicolumn{2}{|c|}{ Replication } & \multirow{2}{*}{$\frac{S}{n}$ ratio } \\
\cline { 2 - 3 } & $S W_{1}$ & $S W_{2}$ & \\
\hline 1 & $2.11 \times 10^{-9}$ & $2.46 \times 10^{-9}$ & 172.80 \\
\hline 2 & $1.95 \times 10^{-9}$ & $2.11 \times 10^{-9}$ & 173.86 \\
\hline 3 & $2.28 \times 10^{-9}$ & $1.95 \times 10^{-9}$ & 173.48 \\
\hline 4 & $2.85 \times 10^{-9}$ & $2.85 \times 10^{-9}$ & 170.92 \\
\hline 5 & $2.46 \times 10^{-9}$ & $2.65 \times 10^{-9}$ & 171.85 \\
\hline 6 & $1.95 \times 10^{-9}$ & $2.46 \times 10^{-9}$ & 173.08 \\
\hline 7 & $2.65 \times 10^{-9}$ & $3.05 \times 10^{-9}$ & 170.88 \\
\hline 8 & $3.05 \times 10^{-9}$ & $2.65 \times 10^{-9}$ & 170.88 \\
\hline 9 & $4.80 \times 10^{-9}$ & $2.38 \times 10^{-9}$ & 168.50 \\
\hline
\end{tabular}

Table 12

Average $\frac{S}{n}$ ratio for specific wear

\begin{tabular}{|c|c|c|c|}
\hline Level & $A$ & $B$ & $C$ \\
\hline 1 & 173.4 & 171.5 & 172.3 \\
\hline 2 & 172.0 & 172.2 & 171.1 \\
\hline 3 & 170.1 & 171.7 & 172.1 \\
\hline Difference & 3.3 & 0.7 & 1.2 \\
\hline Rank & 1 & 3 & 2 \\
\hline
\end{tabular}

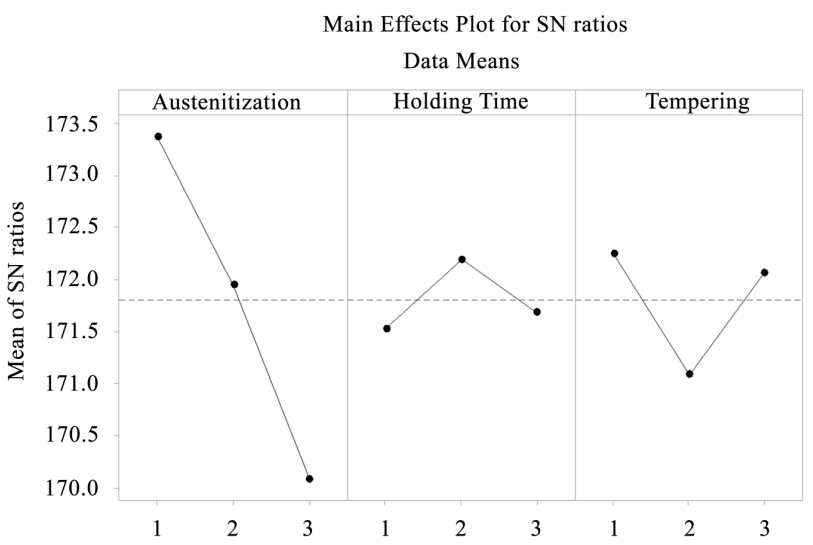

Fig. 4. Graph of the average ratio $\frac{S}{n}$ of specific wear to Level Parameters

Table 13

ANOVA of specific wear

\begin{tabular}{|c|c|c|c|c|c|c|}
\hline Source & $S_{\text {source }}$ & $v A$ & $M_{\text {source }}$ & $F_{\text {ratio }}$ & $F_{\text {total }}$ & $p A \%$ \\
\hline Austenitization (A) & $1.33 \times 10^{-18}$ & 2.00 & $6.68 \times 10^{-19}$ & 26.09 & 3.98 & 70.37 \\
\hline Holding (B) & $5.52 \times 10^{-20}$ & 2.00 & $2.76 \times 10^{-20}$ & 1.08 & 3.98 & 2.92 \\
\hline Tempering (C) & $2.22 \times 10^{-19}$ & 2.00 & $1.11 \times 10^{-19}$ & 4.33 & 3.98 & 11.75 \\
\hline Error & $2.82 \times 10^{-19}$ & 11.00 & $2.56 \times 10^{-20}$ & - & - & 14.96 \\
\hline Total-1 & $18.89 \times 10^{-19}$ & 17.00 & - & - & - & 100.00 \\
\hline
\end{tabular}

Table 14

Updated ANOVA of specific wear

\begin{tabular}{|c|c|c|c|c|c|c|}
\hline Source & $S_{\text {source }}$ & $v A$ & $M_{\text {sorce }}$ & $F_{\text {ratio }}$ & $F_{\text {total }}$ & $p A \%$ \\
\hline Austenitization (A) & $1.33 \times 10^{-18}$ & 2.00 & $6.68 \times 10^{-19}$ & 26.09 & 3.98 & 70.37 \\
\hline Tempering (C) & $2.22 \times 10^{-19}$ & 2.00 & $1.11 \times 10^{-19}$ & 4.33 & 3.98 & 11.75 \\
\hline Pooled Error & $3.37 \times 10^{-19}$ & 13.00 & $5.32 \times 10^{-20}$ & - & - & 17.88 \\
\hline Total-1 & $12.00 \times 10^{-9}$ & 17.00 & - & - & - & 100.00 \\
\hline
\end{tabular}

6. Discussion of experimental results

\section{1. Hardness}

Based on ranking, the effect of heat treatment parameters on hardness is temper temperature, austenitization and holding time (Tables 4, 6 and Fig. 1).

Martensite and residual stresses are produced together by previous quenching. Martensite hardness is increased metallurgically. Residual stress increasing the hardness mechanically due to the dense microstructure but increases crack susceptibility and needs to be reduced. The residual stress can be released by a tempering temperature of $150{ }^{\circ} \mathrm{C}$ because there is no martensite diffusion by temper heat (because it is still below $M_{F}=182{ }^{\circ} \mathrm{C}$ to $192{ }^{\circ} \mathrm{C}$ ). If the tempering temperature is above the martensite finish temperature, the hardness will be reduced by temper heat activation.

The second rank is austenite temperature. The hardness of $544.44 \mathrm{HVN}=512 \mathrm{BHN}$ and decreased at level 2 $(526 \mathrm{VHN}=495 \mathrm{BHN})$ and highest hardness $(544.78 \mathrm{VHN}=$ $=512 \mathrm{BHN})$. Level 1, 2 and 3 have a slightly increased hardness (and ununiform hardness is produced). Nonuniform hardness due to unsTable austenite temperature consequently is the ununiform austenite structures, and ununiform martensite is produced.

The third rank is holding time. Level 1 producing $535.44 \mathrm{VHN}$ and increase to $537.89 \mathrm{VHN}=506 \mathrm{BHN}$ (at level 2). At level 3 producing $541.89 \mathrm{VHN}=510 \mathrm{BHN}$ (highest hardness). Holding for a longer time will decrease the hardness because of martensite diffusion. The pattern of hardness influenced by austenite temperature, the higher the temperature will produce coarse austenite. Austenite holding time and tempering temperature have the same trend.

Temper temperature is the heat treatment parameter most influencing hardness. Hardness slightly decreases by the release of residual stress and ductility increases.

From the ANOVA of hardness, the contribution of heat treatment parameters (austenitization, holding, and tempering) is shown in Table 6 and Table 7. Austenite temperature, holding time and temper temperature have contributed to the hardness of steels, namely:

1) A factor of austenite temperature. $F_{\text {calculate }}(9.41)>$ $>F_{\text {total }}(3.49)$. Then $H_{1}$ is accepted, meaning there is an effect of austenite temperature on steel hardness.

2 ) Factor of holding time. $F_{\text {calculate }}(0.86)<F_{\text {total }}(3.49)$. Then $\mathrm{H}_{1}$ is rejected, meaning there is no effect of holding time on steel hardness.

3) Factor of tempering temperature. $F_{\text {hitung }}(27.88)>F_{\text {total }}$ (3.49). Then $H_{1}$ is accepted, meaning there is an influence of tempering temperature on steel hardness.

From the data above, the predictive value of hardness and the confidence interval for measuring the deviation of the predicted value can be calculated. Hardness predictions are calculated using equations (14)-(16) as follows.

Hardness prediction

$$
\begin{aligned}
& H_{p}=538.41+\left(A_{3}-538.41\right)+\left(C_{1}-538.41\right) ; \\
& H_{p}=538.41+(544.78-538.41)+(560.11-538.41) ; \\
& H_{p}=566.48 \mathrm{VHN} \approx 532 \mathrm{BHN} .
\end{aligned}
$$

Efficiency for hardness 


$$
n_{\text {eff }}=\frac{27}{2+2+2}=4.5
$$

Confidence interval for hardness

$$
C I=\sqrt{\frac{3.49 \times 205.69}{4.5}}=12.63 \mathrm{VHN}=13 \mathrm{BHN} .
$$

Hardness

$$
\begin{aligned}
& H=H_{p} \pm C I \\
& H_{p}=566.48 \mathrm{VHN} \approx 532 \mathrm{BHN} ; \\
& H=(566.48 \pm 12.63) \mathrm{VHN} \approx(532 \pm 13) \mathrm{BHN} .
\end{aligned}
$$

In data processing, take level three because the minimum level is permitted. Another consideration is seeing the trend of hardness after the heat treatment process. For industry is done by scaling because of the significant specimen need for concern. The response value for hardness changes due to the heat treatment parameters and level are used.

\section{2. Specific wears}

Based on ranking, the effect of heat treatment parameters on wear is austenitization, tempering temperature and holding time (Tables 10, 12 and Fig. 3).

The higher the austenite temperature, the coarser austenite grain size will be produced (the coarser the austenite the harder and more brittle martensite will be produced when quenching is finished). If the quench is held as close as possible to $A r_{3}$ (still above $A r_{3}$ ), the fine martensite grain structure will be obtained. High hardness causes brittle material and decrease in specific wear. So, specific wear needs hardness and ductility.

The second rank is temper temperature. Specific wear fluctuating $2.45 \times 10^{-9} \frac{\mathrm{mm}^{2}}{\mathrm{~kg}}$ goes up to level two $2.80^{2} \times$ $\times 10^{-9} \frac{\mathrm{mm}^{2}}{\mathrm{~kg}}$ and goes down to level three $2.51 \times 10^{-9} \frac{\mathrm{mm}^{2}}{\mathrm{~kg}}$. Specific wear fluctuations are caused by changes in time for tempering. Tempering temperature increases the decrease in specific wear.

The third rank is holding time, and the specific wear decreases slightly. Possible decrease in hardness causes the fact that the structure is not sTable yet during the holding, and these structures need enough time to reach a sTable condition. STable conditions will improve steel ductility (in this case, in quenched and tempered steel). STable condition is the structures that do not move when heating during the holding time.

The ANOVA for specific wear, austenitization, holding and tempering are shown in Tables 13, 14. Heat treatment parameter has contributed to the specific wear of steel, namely:

1. Factor of austenite temperature. $F_{\text {ratio }}(26.09)>$ $>F_{\text {total }}(3.98)$. Then $H_{1}$ is accepted, meaning there is a significant effect of austenite temperature on specific wear of hot rolled plate steel.

2. Factor of holding time. $F_{\text {ratio }}(1.08)<F_{\text {total }}(3.98)$. Then $H_{1}$ is rejected, meaning there is no sign of holding time effect on specific wear of hot rolled plate steel.

3 . Factor of tempering temperature. $F_{\text {ratio }}(4.33)<$ $<F_{\text {total }}(3.98)$. The $\mathrm{H}_{1}$ is accepted, meaning there is a significant influence on specific wear of hot rolled plate steels.
From the data above, the predictive value of specific wear and the confidence interval for measuring the deviation of the predicted value were determined. Specific wear predictions were determined using equations (14)-(16) as follows.

Specific wear prediction

$$
\begin{aligned}
& S W_{p}=2.58 \times 10^{-9}+\left(2.14 \times 10^{-9}-258 \times 10^{-9}\right)+ \\
& +\left(2.45 \times 10^{-9}-2.58 \times 10^{-9}\right) ; \\
& S W_{p}=2.01 \times 10^{-9} \frac{\mathrm{mm}^{2}}{\mathrm{~kg}} .
\end{aligned}
$$

Efficiency for specific wear

$$
n_{e f f}=\frac{18}{2+2+2}=3.6
$$

Confidence interval for specific wear

$$
C I=\sqrt{\frac{3.98 \times 5.32 \times 10^{-20}}{36}}=2.42 \times 10^{-10} \text {. }
$$

Specific wear

$$
S W_{p}=(2.01 \pm 0.242) \times 10^{-9} \frac{\mathrm{mm}^{2}}{\mathrm{~kg}} .
$$

Specific wear response values change because of the heat treatment parameters and levels used.

\section{Conclusions}

The research activities have completed and can be summarized as follows.

1. The orthogonal matrix with three levels to optimize the heat treatment parameters for wear and tear is $L_{9}\left(3^{4}\right)$. This matrix is sufficient to determine the contribution of heat treatment parameters to hardness and wear. The heat treatment parameters most influencing hardness and wear are the austenite temperature at level $3\left(\right.$ at $900{ }^{\circ} \mathrm{C}$ ) and tempering temperature at level $1\left(150^{\circ} \mathrm{C}\right)$.

2. Optimization for hardness and wear is predicted to be around $566.48 \pm 12.63 \mathrm{HVN}=(532 \pm 13) \mathrm{BHN}$ and $(2.01 \pm$ $\pm 0.242) \times 10^{-9} \frac{\mathrm{mm}^{2}}{\mathrm{~kg}}$, respectively.

3. The closest the austenite temperature to the $A r_{3}$ line, the most refined austenite structure is, and fine martensite is produced when the quenching is finished. The fine grain structure will increase ductility. Ductility is increased by tempering at $150{ }^{\circ} \mathrm{C}$, this temperature releases residual stress only, and there is no martensite diffusion. The holding time to obtain structural stability during austenite heating and tempering and a Table structure on warming will produce a homogenous microstructure.

\section{Acknowledgments}

The author would like to thank Pradika Andarisa (Mechanical Engineer) for his technical assistance. This assistance in the preparation of the optimal calculation using Minitab 18 in this article is gratefully acknowledged. 


\section{Reference}

1. Madhusudhan Reddy G., Mohandas T., Papukutty K. Enhancement of ballistic capabilities of soft welds through hardfacing // International Journal of Impact Engineering. 1999. Vol. 22, Issue 8. P. 775-791. doi: https://doi.org/10.1016/s0734-743x(99)00020-2

2. Dynamic fracture toughness of armour grade quenched and tempered steel joints fabricated using low hydrogen ferritic fillers $/$ Magudeeswaran G., Balasubramanian V., Sathyanarayanan S., Reddy G. M., Moitra A., Venugopal S., Sasikala G. // Journal of Iron and Steel Research International. 2010. Vol. 17, Issue 5. P. 51-56. doi: https://doi.org/10.1016/s1006-706x(10)60099-4

3. Magudeeswaran G., Balasubramanian V., Madhusudhanreddy G. Hydrogen induced cold cracking studies on armour grade high strength, quenched and tempered steel weldments // International Journal of Hydrogen Energy. 2008. Vol. 33, Issue 7. P. 18971908. doi: https://doi.org/10.1016/j.ijhydene.2008.01.035

4. Demir T., Übeyli M., Yıldırım R. O. Effect of Hardness on the Ballistic Impact Behavior of High-Strength Steels Against 7.62-mm Armor Piercing Projectiles // Journal of Materials Engineering and Performance. 2009. Vol. 18, Issue 2. P. 145-153. doi: https:// doi.org/10.1007/s11665-008-9288-3

5. Sampath K. How to Choose Electrodes for Joining High-Strength Steels // Welding Journal. 2007. P. 26-28. URL: https://app.aws.org/ www/wj/2007/07/WJ_2007_07.pdf?_ga=2.143746806.298708127.1558695448-1529157542.1558695448

6. Messler R. W. Principles of Welding. John Wiley \& Sons, 1999. doi: https://doi.org/10.1002/9783527617487

7. Krauss G. Martensite in steel: strength and structure // Materials Science and Engineering: A. 1999. Vol. 273-275. P. 40-57. doi: https://doi.org/10.1016/s0921-5093(99)00288-9

8. Effect of tempering conditions on wear resistance in various wear mechanisms of H13 steel / Wei M. X., Wang S. Q., Wang L., Cui X. H., Chen K. M. // Tribology International. 2011. Vol. 44, Issue 7-8. P. 898-905. doi: https://doi.org/10.1016/j.triboint.2011.03.005

9. Dziurka R., Pacyna J. The influence of carbon content on the kinetics of phase transformations of undercooled austenite of the Cr-Mn-Mo model alloys // Archives of Materials Science and Engineering. 2011. Vol. 47, Issue 2. P. 77-84.

10. Effect of Tempering Temperature on Microstructure and Properties of E690 Offshore Plate Steel / Zhang J., Cai Q., Wu H., Zhang K., Wu B. // Journal of Iron and Steel Research International. 2012. Vol. 19, Issue 3. P. 67-72. doi: https://doi.org/10.1016/s1006706x(12)60076-4

11. Effect of tempering temperature, plate thickness and presence of holes on ballistic impact behavior and ASB formation of a high strength steel / Mishra B., Jena P. K., Ramakrishna B., Madhu V., Bhat T. B., Gupta N. K. // International Journal of Impact Engineering. 2012. Vol. 44. P. 17-28. doi: https://doi.org/10.1016/j.ijimpeng.2011.12.004

12. Effects of auto-tempering behaviour of martensite on mechanical properties of ultra high strength steel sheets / Matsuda H., Mizuno R., Funakawa Y., Seto K., Matsuoka S., Tanaka Y. // Journal of Alloys and Compounds. 2013. Vol. 577. P. S661-S667. doi: https://doi.org/10.1016/j.jallcom.2012.04.108

13. Persson E. Austenite grain growth in bearing steels. An investigation on steel grades $100 \mathrm{Cr} 6$ and $100 \mathrm{CrMnMoSi8}-4-6$. Stockholm, 2014. $97 \mathrm{p}$.

14. Zdravecká E., Tkáčová J., Ondáč M. Effect of microstructure factors on abrasion resistance of high-strength steels // Research in Agricultural Engineering. 2014. Vol. 60, Issue 3. P. 115-120. doi: https://doi.org/10.17221/20/2013-rae

15. Variation of Creep Resistance in Ferritic Steels by a Heat Treatment / González G., Molina R., Delavalle M., Moro L. // Procedia Materials Science. 2015. Vol. 9. P. 412-418. doi: https://doi.org/10.1016/j.mspro.2015.05.011

16. Effects of tempering mode on the structural changes of martensite / Saha D. C., Biro E., Gerlich A. P., Zhou Y. // Materials Science and Engineering: A. 2016. Vol. 673. P. 467-475. doi: https://doi.org/10.1016/j.msea.2016.07.092

17. Ebrahimian A., Ghasemi Banadkouki S. S. Mutual mechanical effects of ferrite and martensite in a low alloy ferrite-martensite dual phase steel // Journal of Alloys and Compounds. 2017. Vol. 708. P. 43-54. doi: https://doi.org/10.1016/j.jallcom.2017.02.287

18. Hidalgo J., Findley K. O., Santofimia M. J. Thermal and mechanical stability of retained austenite surrounded by martensite with different degrees of tempering // Materials Science and Engineering: A. 2017. Vol. 690. P. 337-347. doi: https://doi.org/10.1016/ j.msea.2017.03.017

19. Hosmani S. D., Kurhatti R. V., Kabadi V. K. Wear Behavior of Spherodized Cementite in Hyper Eutectoid Plain Carbon Steel // International Advanced Research Journal in Science, Engineering and Technology. 2017. Vol. 4, Issue 7. P. 257-262. URL: https:// iarjset.com/upload/2017/july-17/IARJSET\%2044.pdf

20. An atomic mechanism for the formation of nanotwins in high carbon martensite / Chen Y., Ping D., Wang Y., Zhao X. // Journal of Alloys and Compounds. 2018. Vol. 767. P. 68-72. doi: https://doi.org/10.1016/j.jallcom.2018.07.099

21. Wear investigation of selective $\alpha-\mathrm{Fe}_{2} \mathrm{O}_{3}$ oxide layers generated on surfaces for dry sheet metal forming / Behrens B.-A., Yilkiran D., Schöler S., Özkaya F., Hübner S., Möhwald K. // Procedia Manufacturing. 2018. Vol. 15. P. 923-930. doi: https://doi.org/10.1016/ j.promfg.2018.07.404

22. Laboratory team, 2019, Modul Praktikum Uji Aus (Indonesian). Mechanical Engineering Departement, Faculty of Engineering, Yogyakarta, Gadjah Mada University.

23. Soejanto, Irwan. Desain Eksperimen dengan Metode Taguchi. Yogyakarta, Graha Ilmu, 2009.

24. Krishnaiah K., Shahabudeen P. Applied Design of Experiments and Taguchi Methods. New Delhi, 2012. 371 p. 